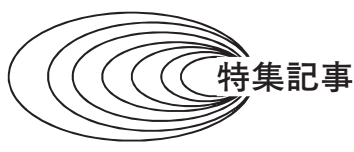

\title{
「見える化」特集にあたっで
}

\author{
横野 泰之**，小山田 耕二***
}

\section{"Mieruka" feature article}

\author{
Yasuyuki YoKono and Koji Koyamada
}

可視化情報学会にて，「見える化」の特集を組むとい うのは奇妙に感じられるかもしれない。「見える化」は 科学技術の言葉では「可視化」そのものであるからであ る。世の中では，「見える化」は問題を見えるように工 夫し，問題を理解してその解決を四ることを意味してい る。日本では世界に先駆け，その效能をモノづくりの現 場に活用してきた経緯がある。最近では，この「見える 化」は生産現場だけでなく, 設計などの製品開発や経営, 教育など，様々な領域で実践されつつある。本特集にお ける「見える化」はこのような情報の可視化技術として 捉えている。現象の観察だけでなく，得られた知見を利 用して解決策を生み出す手段である。対象は物理現象の みならず，設計，開発，プロジェクト，教育といったな かなか定量化が難しい問題も含んでいる。ささまざまな情 報を, 人間が理解できる形に変換し，その本質をつかみ， 課題解決を図るといった「情報の可視化」技術として本 特集を企画したものである。

そも气も，本学会は昭和 56 年に「流れの可視化学会」 としてスタートしている. 流れの可視化は流れ場の速 度・温度など熱物質移動を非接触で定量的に多次元計測 するための方法として発展を続け, 現在では機械・造 船・航空・宇宙・土木・建築・海洋・気象などの理工学 分野に加え, 医学・農学・環境学といった様々な分野で 有力な研究・開発手段として活用されるようになり，本 学会は, 流れの可視化に関する研究・開発において, 世 界の「流れの可視化技術」をリードしてきた。一方，平 成 2 年には，様々な分野における「情報の可視化」に関 する研究・開発にも積極的に取り組むことも視野に入れ るべく, 社団法人「可視化情報学会」として改組してい る。このように二十数年にわたり,「見える化」に取り 組んできている学会が, 改好て現在の技術を特集し, こ の分野の専門家である会員に, 現在の進展を感じていた

* 原稿受付 2011 年 2 月 25 日

** 正会員 東京大学大学院工学系研究科 ( $=113-8656$ 東京都文京区本郷 7-3-1 E-mail : yokono@mech.t.u-tokyo.ac.jp)

*** 正会員 京都大学高等教育研究開発推進センター (₹ 606-8501 京都市左京区吉田二本松町

E-mail : koyamada.koji.3 w@ kyoto-u.ac.jp)
だきたいと考えている. 本特集では，異なる分野から 5 名の方に執筆をお願い した。東北大学の大林先生からの「航空機設計空間の見 える化」では, 設計案を決定することを目的とし, 数值 流体力学，最適化，データマイニングを駆使して設計空 間を可視化された例をご紹介いただいた。 上記に掲げた 「問題を見えるように工夫し，問題を理解してその解決 を図る」ことを実践されている好例といえる。

日立製作所の鈴木氏，高野氏，本多氏，堀内氏，安田 氏の「製品開発における見える化」では，企業における 可視化の利用について，様々な物理現象を見ることの有 用性を述べていただいた。その分野の専門家が物理現象 を把握することにより，企業における製品開発に寄与で きることがよくわかる.

リコーの宮澤氏からは「複写機・プリンター開発の見 える化」として，設計知識の可視化を紹介いただいた。 設計ノウハウの蓄積, 活用といった日本の設計技術, 特 にすり合わせ製品での日本の強みを生かしている例を捧 察した。

筑波大学の木野先生からは，「ソフトウェア開発プロ ジェクトの見える化」を紹介いただいた。成果物が見え ずらいソフトウエアを対象に，作業，進捗，リスクを可 視化したものである。様々なプロジェクト状況を把握す る手法として参考となる.

名古屋大学の梶田先生には，「大学における教育学習 活動の見える化」として，実際に参加して講義を受けて みた後でないとわからなかった教育学習活動を電子化に より, 予め, 第三者にも理解できるようにする活動が紹 介されている。

これらいずれの例も, 広範囲の分野での応用, 発展が 期待できるものと考えられる。様々な分野で「見える 化」が求められ, 計算機の情報処理やその手法の発展が, その基盤となっていることもよくわかる.

この特集記事が，目に見えない現象を可視化してきた 本学会の会員の皆様にとって, 世の中で求められ, より 多くの人が関係する, これから取り組むべき課題の一つ であると感じていただけば甚だ幸いである。 